\title{
Collaborative Research on Cross-Border E-Commerce Logistics in Zhengzhou
}

\author{
Xueyuan Wang, Huixian Zhang \\ Administrative Engineering College, Zhengzhou University, No.100 science Avenue, Zhengzhou, China \\ 1575832531@qq.com; Zhanghuixian1995@163.com
}

Keywords: Cross-border e-commerce; Cross-border logistics; Coordinated development; Zhengzhou

\begin{abstract}
With the development of cross-border e-commerce in China, Zhengzhou has made great achievements in this respect. However, there are still many problems in the cooperation between cross-border e-commerce and cross-border logistics. The information fusion is not sufficient, the development of cross-border logistics is relatively backward, the cooperation between cross-border e-commerce and reverse logistics is missing. To solve these problems, the paper puts forward the balanced interests to promote cross-border electricity and cross-border logistics information sharing, accelerates the construction of cross-border logistics, the introduction of cross-border logistics outsourcing services and government policy support and so on.
\end{abstract}

\section{INTRODUCTION}

Cross-border electricity commerce development in our country has experienced the germination period, development period, outbreak period and development until now, already has a certain scale. Cross-border ecommerce market size has increased from 4.2 trillion yuan in 2014 to 5.4 trillion yuan in 2015; Even in the first half of 2016, cross-border electricity commerce by the impact of the New Deal, the scale of cross-border electricity still climbed to 2.6 trillion yuan, up 30\% from a year earlier. In 2016, global e-commerce retail turnover of 1.9 trillion, compared with $23.7 \%$ growth, electricity retail sales accounted for $8.7 \%$ of global social total retail sales of commodities. According to the forecast, to 2020 , this proportion will reach $14.6 \%$. Cross-border electricity commerce will be a big cake, which has great development potential.

Zhengzhou as China's transport hub, which is the important foundation to developed logistics. In 2016, Zhengzhou, Chongqing, Hangzhou, Ningbo and Shanghai approved cross-border e-commerce pilot cities. The cross-border electronic business growth and overall business volume increased steadily in Zhengzhou. Commodity amount from 1.02 billion in 2014 to 6.65 billion yuan in 2016, and even to 5.01 billion yuan in the first half of this year, keeping high-speed growth.The cross-border electricity commerce supplier and crossborder logistics is complementary to the formation, vigorously promote the further development of crossborder cross-border logistics, while cross-border logistics development also can promote the further development of cross-border electricity. The crossborder electricity supplier logistics effectively and crossborder cooperation, to reduce logistics costs and improve logistics efficiency. Therefore, cross-border electricity commerce supplier has received national attention, can promote the reform of cross-border trade supply side structure, the optimization and upgrading of foreign trade structure.

At home and abroad for the cross-border logistics and cross-border e-commerce collaborative have made some progress. Abroad mainly concentrated in the distribution mode, distribution effect, quality of service and supply chain system; domestic research in research and development and relationship coordination (Minghua Dai, Chujun li,2017), collaborative evaluation (Zhan Cao, 2017), coordination mechanism research (Xiaheng Zhang, Hailing Guo,2016), research on collaborative cross-border logistics and supply chain system, coordination several problems of research and collaborative research and countermeasures.

\section{THE CONNOTATION OF CROSS-BORDER E- COMMERCE AND CROSS-BORDER LOGISTICS COOPERATION}

The cooperation between cross-border e-commerce and cross-border logistics is mutually reinforcing, and the synergistic co-existence and common development of the two subsystems are mutually integrated. The mutual promotion and restriction between cross-border e-commerce and cross-border logistics constitute a complex and changing cross-border e-commerce ecosystem. Cross-border electricity supplier ecological system refers to the cross-border business, cross-border logistics enterprises and other related to cross-border electricity trading activities of individuals, enterprises, institutions and other organizations, communities and the political, economic, cultural, social environment and living environment constitute a unified whole, the population and environment interaction, cooperation, through the commodity, logistics, funds circulation and information sharing and a dynamic balance system(Jing He, Huimin Qian,2017). The current trading mode of cross-border e-commerce is mainly B2B and B2C. Among these two modes, there are five nodes: Chinese manufacturers, network operators, cross-border ecommerce platforms, foreign network operators and foreign consumers. Among them, Chinese manufacturers, cross-border e-commerce platforms, foreign consumers are essential

Cross-border e-commerce play a very important role in the transaction, In this cross-border e-commerce system, cross-border e-commerce is the core species. 
Which is between the supply of goods and consumer media, suppliers in the manufacturers, play a very important role in intermediary distributors and consumers of whole supply chain. From the perspective of cross-border e-commerce ecosystem, the cooperation between cross-border e-commerce and cross-border logistics is the smooth flow of goods flow, information flow, capital flow and logistics between logistics (Xiao Ning Wang, Anyu li,2016). From the angle of supply chain, in the process of cross-border electricity trading, in the process of goods from producer to consumer, in fact is a kind of supply chain activities, through strengthening cooperation among each node of supply chain, to promote the coordination of the supply chain.

\section{ZHENGZHOU CROSS-BORDER E- COMMERCE AND CROSS-BORDER LOGISTICS DEVELOPMENT FOUNDATION}

The establishment of Zhengzhou Xinzheng airport comprehensive bonded zone; In 2013, Zhengzhou was approved as a pilot city for cross-border e-commerce services. In e-commerce development, compared with Zhejiang, Shanghai and other places there are also some backward, but in terms of cross-border electricity, may bend overtaking, particularly in the import and export of cross-border e-commerce can bring a lot of to Zhengzhou airport cargo flow, thereby giving impetus to the development of related services.

Located in the hinterland of central China, Zhengzhou is an important node on "One Belt and One Road" and an important economic center of the new Eurasian continental bridge. In November 2015, Zhengzhou E-trade passed the national acceptance inspection, becoming the most mature business model with the most innovative and replicated promotion in the country. Zhengzhou trade mode to realize the rapid development of E-business single treatment of annual accumulative total amount exceed 50 million, achieved 241.3\% growth, Zhengzhou E-trade through the business model and a series of innovation success to build the " internet silk road”. The Central Plains region, which has no advantage of relying on the sea, has succeeded in getting rid of the geographical disadvantage, and has the unique advantages of its development. In 2016, it was approved to be a pilot city of cross-border e-commerce, and gave great support to the development of the crossborder e-commerce in Zhengzhou.

Zhengzhou's logistics aviation port is an important pillar to develop cross-border electricity suppliers and cross-border logistics, the construction of Zhengzhou international logistics park, is to improve the quality of logistics. The airport has a natural transportation advantage, airspace conditions, cargo throughput keeping growth, China airport, cargo flights in Western China second major airports, air docking, multimodal transport, modern integrated transport system in the Czech foreign smooth is increasingly perfect, is an important guarantee for the development of cross-border electricity supplier in Zhengzhou city.

\section{THE CROSS-BORDER LOGISTICS AND CROSS-BORDER E-COMMERCE PROBLEMS IN ZHENGZHOU}

While cross-border e-commerce is developing rapidly, many problems in the industry, especially in cross-border e-commerce and cross-border logistics, are gradually being valued. Cross-border electricity cost is high, distribution efficiency and service quality, blasting warehouse, goods backlog, damaged or even lost event has occurred, cross-border electricity and cross-border logistics has a lot of problems.

\subsection{Insufficient information fusion between cross- border e-commerce and cross-border logistics}

Electronic commerce is an industry developed gradually with the development of information technology, which depend on information. At present, the logistics industry is more and more involved in the application of information technology, transportation database, logistics status tracking and other information technology, to achieve the control of the logistics process. However, the information fusion sharing between cross-border e-commerce and cross-border logistics has brought great obstacles to the development of the two industries.

On the one hand, cross-border logistics enterprises cannot obtain the first-hand data of e-commerce enterprises. Cross border electricity supplier in trade involves not only producers, network operators, electronic business platform, foreign network operators and consumers, in the logistics process will also involve import and export customs, national inspection and other issues. Cross-border logistics has no perfect e-commerce information, can't build a targeted logistics system for its e-commerce users, nor can it predict its logistics status to respond to the measures. Led to the cross-border electricity supplier in the construction process is relatively slow progress; On the other hand, Cross border electricity suppliers are not fully aware of the information of cross-border logistics enterprises. They can not fully understand the logistics carrying capacity of logistics enterprises, and can not accurately grasp the entire cross-border transportation network of logistics enterprises, lead to the slow transportation speed, low efficiency, reduce the consumer's satisfaction. But in the current development, cross-border logistics and crossborder electricity enterprises for their own interests, not completely realize the information sharing, the data of both sides are still blocked, hindering the development of the industry.

Of course, Zhengzhou is currently in the cross-border business informatization construction is not perfect. The current Zhengzhou cross-border electricity supplier more use of postal parcel logistics information, there is no way to track, many users can not be the first time to get effective information. Secondly, the design of domestic cross-border electricity supplier, in two markets, the exchange of information between the two will take some time, because the time difference will cause the information gap, the cross-border electricity supplier in Zhengzhou at present also has this problem. 


\subsection{The development of cross-border logistics is not perfect}

Although there are some international logistics parks, logistics airports and other cross-border logistics facilities in Zhengzhou, but the integration ability of cross-border logistics services is still poor. In particular, in order to speed up the logistics speed and choose Fedex, TNT, USP, DHL international logistics, resulting in high transportation costs, so that the overall cost is high, forming a trade disadvantage. The development of domestic logistics enterprises is still far from the development of international logistics enterprises. The development level of storage facilities, distribution efficiency, information processing and logistics system is not enough. The service function of logistics enterprise is relatively single, providing only one or two service functions such as express delivery, direct mail, customs clearance, transportation forwarder, etc., which is difficult to realize the integration of logistics resources around the world.

Zhengzhou international logistics park has unique geographical position advantage and good economic foundation, especially the development of agricultural products logistics. However, the international logistics park also has short development board, such as low level of informatization, shortage of talents and insufficient freight volume and so on. Zhengzhou logistics aviation port is still in the construction of the first phase, basically has initially completed a relatively perfect industrial zone. Although has made great construction achievements, but there are still some problems restrict the development of cross-border logistics, aviation port logistics cost, the logistics cycle time is long, informatization construction is not perfect and lack of effective marketing mechanism has hindered the development of cross-border electricity providers. Cross border electricity supplier development is very fast and rapid, cross-border logistics development is relatively slow, the development of the two is not synchronized, largely restricting the coordination of cross-border and cross-border logistics.

\subsection{The synergistic deficiency of reverse logistics of cross-border e-commerce}

Reverse logistics is a very common situation in the process of logistics operation, and consumers are not satisfied with the goods, and many other reasons will lead to the reverse logistics. Although the reverse logistics is not large, it is also a very important part of the whole logistics process. Compared with domestic logistics, the impact of international cross-border logistics will be greater. In international logistics, once reverse logistics occurs, it will experience more customs clearance, inspection links, and will increase logistics costs and logistics risks. More logistics departments, more experience of procedures, procedures and other complex will lead to increased logistics cycle, logistics information is inaccurate. Although the process of crossborder logistics in Zhengzhou has been simplified, but the ability to deal with the reverse logistics is still relatively weak, is in a stage of continuous improvement.

\section{THE COUNTERMEASURES OF CROSS- BORDER LOGISTICS AND CROSS-BORDER E- COMMERCE IN ZHENGZHOU}

\subsection{Balance benefits promote cross-border e- commerce and cross-border logistics information sharing}

Cross border electricity suppliers and cross-border logistics enterprises for the protection of their respective interests is an important reason for the information between the two sides does not share. Under the guidance of the government, we should establish a comprehensive and mutually beneficial supply mechanism, and the government can act as a guarantee to establish mutual trust mechanisms between the two sides. On this basis, we can better realize the information sharing, break the barriers of information, and adopt the third party hosting cost and fund operation to promote the fair distribution of interests. In addition, to speed up the construction of information facilities, the government has issued relevant laws and regulations to better integrate information sharing between cross-border logistics and cross-border e-commerce.

\subsection{Accelerate the construction of cross-border logistics}

Speed up the audit of cross-border logistics, customs, commodity inspection departments supporting facilities upgrade, to achieve audit orders, commodity inspection, and some of the process automation, improve customs clearance efficiency. Domestic logistics enterprises should strengthen their cooperation with international logistics enterprises, learn advanced places, improve their own strength and access to more overseas markets. Optimize air transportation network planning, air transport, warehousing and transport facilities to strengthen the construction, improve the efficiency of air transportation; Improve the existing mode of transportation, select the collection, direct mail and other forms according to the actual situation, and reduce the transportation cost (Zhanfeng Zhu,2016). Increase investment in logistics airports, international logistics parks, strengthen the construction of logistics facilities, accelerate the development of cross-border logistics, promote cross-border electricity supplier and crossborder logistics development balance.

\subsection{Introduction of cross-border logistics outsourcing} business

Cross-border logistics itself, the process is complex and complicated formalities, the advantage of the selfbuilt logistics system is more and more not obvious, especially for small and medium-sized electric business enterprise, set up their own logistics system, not only need a lot of money, manpower, a lot of energy will spread enterprise can't focus on their own core competitiveness. At present, the Jingdong, Tmall and other large electricity providers have their own logistics system, but also can use part of logistics outsourcing, third party logistics companies. For example, the Jingdong will be part of the logistics outsourcing to some third party logistics companies, so as to improve 
the level of logistics. The third party logistics is also diversified in cross-border services, international small packages, international express delivery, etc., can provide more specialized services. With the rise of the fourth party logistics, through the integration of various logistics resources, the use of the logistics base at home and abroad, such as information technology, to provide one-stop logistics services. Unify freight, customs, frontier inspection and information to improve the value of logistics services.

For cross-border logistics transportation, Zhengzhou can no longer limited to one mode of transportation, can adopt the hybrid or combined mode of transportation, international postal parcel, international express delivery, overseas warehouse, logistics lines according to the actual form of combination, such as overseas warehouse + international postal parcel, play integration effect, to achieve the " $1+1>2$ " effect.

\subsection{Government policy support}

Any industry wants to develop faster, it needs the strong support from the government. Government should formulate and implement policies and measures to speed up the development of modern logistics, set and launch preferential policies to attract private capital into the logistics industry, and guide social forces to build logistics through tax reduction and other effective measures; Continue to innovate "special commodity port + cross-border electricity supplier", "China Europe class (Zhengzhou) + cross-border electricity supplier" and other modes, to support enterprises to carry out crossborder e-commence business; Explore the development mode of "Internet + rural" and expand agricultural products export; Timely launch policies to promote the development of the current market logistics industry, the current obstacles to the development of logistics policy in time "clean up", and promote the fair mechanism of the market. Provide a fair, open, transparent and efficient legal regulation system for the development of logistics industry, and promote the development of cross-border logistics in a more rational way. To promote the cooperation between government, enterprises, colleges and universities, associations, the construction of crossborder television talent training base, depth development of curriculum system, practice, lead the students real fuck conveying a batch of cross-border electricity business.

\section{CONCLUSIONS}

Through the study of coordination of cross-border ecommerce in Zhengzhou and cross-border logistics, Zhengzhou currently in the existing problems, and puts forward the countermeasures to solve the problem, promote the development of cross-border electricity supplier in Zhengzhou, Zhengzhou to stimulate the economy, but also pave the way for the future development of Zhengzhou into the electricity supplier. This paper is mainly on the qualitative level, can be further consider a study from a quantitative point of view. In addition, we should pay attention to the combination of cross-border and cross-border electricity supplier logistics and practice, theory and practice, qualitative and quantitative. Promote cross-border and cross-border electricity supplier logistics localization, cross-border industry has the characteristics of Zhengzhou.

\section{ACKNOWLEDGEMENTS}

This research is supported by National Natural Science Foundation of China (Grant No. U1604150), Humanities \& Social Sciences Research Foundation of Ministry of Education of China (Grant No. 15YJC630148), Distinguished Young Teacher Development Foundation of Zhengzhou University (1421326092), and Key Research Foundation of University Education in Henan province (17A520058). The authors would like to thank the editors and anonymous referees for their careful and fruitful comments to improve the quality of this paper.

\section{REFERENCES}

[1] Jiang He, Huimin Qian, 2017. Research on Coordination Strategy of cross border electricity supplier and cross border Logistics, Logistics Management,40(70, pp,1-6.

[2] Minghua Dai., 2017.Research on coordinated development of cross border electricity supplier and logistics industry, Logistics Management,40(4), pp.7-10.

[3] Xiaoning Zhu, Anyu li, 2016. Research on coordinated development of cross border electricity supplier and logistics in big data Era, Management Engineer ,21(1), pp.5-7.

[4] Xiaheng Zhang, Hailing Guo, 2016.Cross border electricity supplier and cross border logistics synergy: mechanism and pat, CBAM,30(11), pp.83-92.

[5] Zhanfeng Zhu, 2016. Discussion on coordinated development of Ningbo electricity supplier and logistics industry, Ningbo Economic,04, pp.17-20.

[6] Zhan Cao, 2017. Research on collaborative evaluation model construction of cross border electricity supplier and logistics -- Based on the synergy degree model of composite system, Chinese Business Theory, (22) pp.52-54. 